\title{
Investigating the reasons for failures and delays in $R \& D$ projects with the project management approach
}

Saeed Ghorbani ${ }^{1 *}$, Shayan Naghdi Khanachah ${ }^{2}$

Faculty of Industrial Engineering, Malek Ashtar University of Technology, Tehran, Iran ${ }^{1,2}$ sgh14@yahoo.com $^{1 *}$, shayan.en24@gmail.com ${ }^{2}$

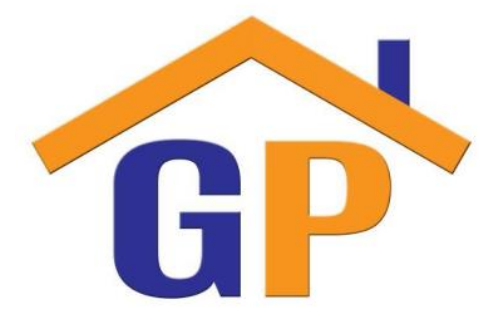

\section{Article History}

Received on 1 May 2021

Revised on 22 May 2021

Accepted on 31 May 2021

\begin{abstract}
Purpose: This study aimed to identify and investigate the reasons for failures and delays in $R \& D$ projects with an organizational productivity approach.

Research methodology: In order to identify the most influential factors in the research area, a questionnaire with a Likert spectrum of five options was designed and distributed among the stakeholders of research projects. The questionnaire results were analyzed and 10 more effective factors were identified and solutions were used to improve the situation.

Result: In the present study, after reviewing the background of the subject and reviewing previous studies, 149 factors affecting the failure and delay of projects were identified and after aggregating and summarizing the factors, a model was designed to classify the causes of delay in which 55 effective factors in two general categories. Intra-organizational and extra-organizational factors were examined.
\end{abstract}

Limitations: This research only described Research-oriented organizations.

Contribution: According to the analysis results regarding the more effective causes, problems and challenges related to each of the factors were studied and to reduce the impact of existing factors, various solutions and suggestions in the field of research variables using Expert opinion was provided.

Keywords: Project, Project management, Planning, Scheduling, Success, Failure, Delay

How to cite: Ghorbani, S., \& Khanachah, S. N. (2020). Investigating the reasons for failures and delays in $R \& D$ projects with the project management approach. Annals of Management and Organization Research, 1(4), 319-334.

\section{Introduction}

Delay is one of the most common phenomena in projects and is one of the main reasons for project failure. Considering that in the treatment of any disease, the first step is to identify it, identifying the factors affecting the delay will be an essential step in improving the implementation process of projects and preventing delays in future projects (Dorji, Rai, Namgay, Pelden, \& Sunwar, 2020; Gondia, Siam, El-Dakhakhni, \& Nassar, 2020).

On the other hand, the project implementation environment is very complex and dynamic. In a way, this dynamic environment distinguishes project management from the management of non-project and ordinary organizations (Prasad, Vasugi, Venkatesan, \& Bhat, 2019). Undoubtedly, the success and survival of a project-oriented organization depend on the success of projects, and one of the criteria for project success is achieving time commitments or not delaying project implementation (M. Zahedi, Akhavan, \& Naghdi Khanachah, 2020). In recent years, projects have faced more time constraints and the ability to deliver projects quickly has become an important factor in winning tenders or 
outperforming competitors. Numerous stakeholders and factors are involved in the implementation of each project, and the negative impact of each of these factors, in addition to the dynamic external environment, increases the likelihood of project delays (Doloi, Sawhney, \& Iyer, 2012).

Delay is an action or event that prolongs a project's schedule; in other words, a delay is an interval between planned and actual project activities. Delay is one of the most common phenomena in projects and is one of the main reasons for project failure (Dorji et al., 2020). Over the past few decades, this phenomenon has occurred in most types of projects, from simple construction projects to the most complex ones, such as petrochemical projects, dam construction, nuclear power plants and tunneling. Delays in projects lead to more resources, reduced profits, or lost opportunities (Durdyev \& Hosseini, 2019). For this reason, most developed and developing countries today, knowing the limited resources available and the highly competitive market, seek to find the root causes of delays in past projects in order to use more resources and make more profit by providing solutions to the rate of delays in projects.

Prevent the future or minimize the damage that is likely to occur (Agyekum-Mensah \& Knight, 2017). Regarding the causes and factors of success, failure and delay of projects, many have been done inside and outside the country and various contents have been mentioned in books related to the field of project management, which can be summarized as follows: Research of Standish Group ${ }^{1}$, Project Management Development Group in the book Competence Framework for Project Managers (Silvius \& Schipper, 2014), PMBOK Guide (Agyekum-Mensah \& Knight, 2017; Al-Momani, 2000; Ali, Smith, Pitt, \& Choon, 2007; AlSehaimi, Koskela, \& Tzortzopoulos, 2013; Assaf \& Al-Hejii, 2006; Buss \& Rosenblatt, 1997; Chiu \& Lai, 2017; Dinakar, 2014; Elawi, Algahtany, \& Kashiwagi, 2016; Fallahnejad, 2013; Frimpong, Oluwoye, \& Crawford, 2003; Gebrehiwet \& Luo, 2017; Guida \& Sacco, 2019; Mahamid, Bruland, \& Dmaidi, 2012; Shabbab Al Hammadi, 2016; Shaikh, Muree, \& Soomro, 2010; Singh \& Williams, 2020; Sprecher, Kolisch, \& Drexl, 1995; Yang \& Wei, 2010). After summarizing the results of research on the causes and factors of success and failure of projects and the causes of project delays, more than 400 influential factors were extracted. After examining the mentioned factors, a number of them that had been repeated in different sources and references were removed and finally reduced to 149 influential factors.

Various methods can be used to categorize the causes of project delays or failures, some of which are as follows: Classification based on the person responsible for the delay, classification based on organizational factors (human factors, organizational factors, etc.), classification based on factors related to the project life cycle, classification based on the impact of project stakeholders (according to the excellence model of project-based organizations), classification based on nine specialized areas of project management (according to PMBOK guideline), classification based on project managers competency framework (according to IPMA Competence baseline), classification based on IPMA Project Excellence Model (Dorji et al., 2020; Sabzehparvar \& Seyed-Hosseini, 2008; T. M. Williams, $\underline{2013)}$.

By reviewing the 149 factors mentioned above, it was concluded that none of the mentioned classification methods could cover all the causes; and a combined model needs to be used to classify the causes. For this purpose, the initial model was prepared and examined from different angles, and finally, after making the necessary corrections, the optimized model of Figure 1 was used, which is able to cover all the 149 causes and factors extracted from previous research. Based on the classification of the mentioned model, 52 categories of factors affecting the success of projects or factors affecting project delays were identified, which are listed in appendix 1 with reference to the authorities.

Currently, many research projects related to the research and development of the organization under study are associated with delays. These delays have imposed many hidden and overt costs to the organization (M. R. Zahedi \& Khanachah, 2020). Costs such as cost of late operation or lost profits, cost of rising consumer resources, increased cost of labor resources, cost of renewing licenses and contracts, cost of capital expenditure, loss of competitive market, uneconomical Project; In fact, it can be said that the implementation of research projects related to research and development in the study organization

\footnotetext{
${ }^{1}$ http://www.standishgroup.com/index.php
} 
is weak and there is a fundamental need for an approach to improve the situation $\underline{(M . ~ R . ~ Z a h e d i ~ \& ~}$ Khanachah, 2019). Therefore, the first step in treatment recognizes the real reasons for project delays.

\section{Literature}

\subsection{Research and development}

The Organization for Economic Co-operation and Development (OECD) defines R\&D as: "Creative work that is done on a systematic basis to harness the resulting scientific and technical knowledge in order to invent new applications" (Woodward, 2004).

The National Science Foundation classifies and defines research as follows:

Basic research: The purpose of basic research is a deeper understanding or knowledge of the subject under study, not its practical application. The National Science Foundation, taking into account the industry's goals, modifies this definition, noting that basic research does not have specific business objectives, although it may be in the current or future interests of the research organization (Zafar, Saud, \& Hou, 2019).

Applied research: The purpose of applied research is to gain the necessary understanding or knowledge to determine how a specific and known need is met. Applied research in industry is discovering new scientific knowledge that pursues specific business objectives for a product or process. Developmental research: "Development is the systematic application of research knowledge or concepts to the production of materials, tools, systems or Useful methods, including the design and production of semiindustrial samples and processes" (Rashidi, Shabani, \& Saen, 2015).

\subsection{Relationship between research activities and technical engineering activities}

Recent research on the principles of definition and implementation of research projects (R\&D) states that: "Engineering research is done to develop new products and services in $R \& D$ centers adjacent to the industry (Attaran, 2004). This research leads to two groups of problem-solving activities: research activities and engineering design activities (León \& Farris, 2011). In a product development research project, both groups of activities need to be identified and distinguished from each other. These two groups of activities have in common that both groups deal with issues related to the development of inhouse technology and the development of products and services (Artz, Norman, Hatfield, \& Cardinal, 2010). The difference between these two groups is that problem-solving in engineering design activities is based on known and codified patterns, while problem-solving in research activities is done without knowing patterns. Research activities should lead to codified methods and patterns to solve a set of similar problems with common characteristics so that activities that are now and in the cultural, social, organizational and current coordinates of the nature of research in the future into activities with the nature of engineering design (Lindkvist, 2005).

\subsection{Project success}

In an article entitled "Recognizing the Key Factors in Project Success in Iran, "Asgari et al. (2017) have introduced the following three criteria as important criteria for judging project success: - Satisfy customer needs - Delivery of the project on time - Completion of the project based on the allocated budget In his book, Advanced Project Management, he argues that in recent years our definition of project success has changed. It provides definitions of project success and a list of failure and success factors that can affect project performance at different stages of a project life cycle (Asgari, Kheyroddin, \& Naderpour, 2017).

Davis (2017) points out, the definitions of project success have changed over the years. In the early days, project success was generally summed up in technical factors: Does the product work or not? With more and more organizations understanding project management and paying more attention to the cost factor, the definition of success also changed. In 1980, the following definition was given for the success of the project: The success of the project means achieving the following three goals (Davis, 2017):

- Finish on time

- Finish with the same set cost

- Finish with the same quality

Normally, the quality of a project was defined as the achievement of technical characteristics. All three of these factors are related to the internal factors of the project and do not necessarily include the 
consumer or customer preferences. In the late 1980s, with the advent of TQM, the success of a project depended not only on three internal factors: time, cost, and technical characteristics, but also on the following factors (Lashgarara, Torabi, \& Omidi Najafabadi, 2016):

- Being acceptable to the customer

- Establishing a business relationship with the customer in future projects.

A project is a complete success when it is executed according to schedule. Its cost is determined within the budget. It is defined according to technical and quality characteristics, and finally, a satisfied and satisfied customer. Successful projects are defined as being within the budget and time frame, fulfilling the intended function, and meeting the expectations of senior management and the user or employer. Westerveld summarizes the success of the project by examining various sources (Kabirifar \& Mojtahedi, 2019):

- Project results (budget, schedule, quality)

- Customer satisfaction

- Satisfaction of users

- Satisfaction of beneficiaries

- Satisfaction of project staff

- Satisfaction of contractors

Sabzehparvar and Seyed-Hosseini (2008) categorize the success and failure components of projects as:

A) Basic components

- Adherence to time frame, cost, quality

- Acceptance of the project produced by the customer

B) Secondary components

- Continue working with the customer

- Comprehensive agreement on the required changes to the project

- Do not disrupt the current work of the organization

- Do not change the culture of the organization

- Maintaining ethical values

- Adherence to organizational strategies

- Maintaining the credibility of the organization.

\subsection{Delay}

\subsubsection{Scheduling delay}

Any failure to complete the activity on time will result in a scheduling delay. Of course, it should always be borne in mind that the non-realization of the plan for each separate activity can be caused by the single delay of that activity or by the delay of the prerequisite activities of that activity. In other words, the delay of any activity will not necessarily lead to the delay of the project (Seyed-Hosseini, Sabzehparvar, \& Nouri, 2007).

\subsubsection{Project delay}

The variance between the estimated project completion time and the actual completion time is called the project delay. This delay will be equal to the sum of the delays of the existing activities on the critical path. A delay is an action or event that prolongs the time specified in the contract to perform a particular action and manifests itself in the form of prolonging the duration of the activity or delaying its start date and may change in some areas of work according to Also include the contract (T. Williams, 2003).

\subsection{Types of delays}

Reams et al. (2009) categorizes types of delays as follows:

2.5.1. Forgivable/Reimbursable

This type of delay occurs due to the fault of the customer or employer and therefore, the contractor or contractor, in addition to extending the project time, also receives compensation for the delay.

\subsubsection{Forgivable/Irreparable}

The reason for this type of delay is neither the employer nor the executor, so only the extension of time of the project occurs and no penalty is received from either party (Reams et al., 2009; Sharifi, Akram, Rafiee, \& Sabzehparvar, 2014). 


\subsubsection{Unforgivable/Irreparable}

This occurs due to the error of the contractor or contractor and the time extension of the project is not approved and naturally, the employer can claim damages (Reams et al., 2009; T. Williams, 2003). Amandin \& Kule (2016), in an article entitled "Project delays on cost overrun risks: A study of Gasabo district construction projects," have categorized the laws of simultaneous delays as follows (Amandin \& Kule, 2016):

Table 1. Types of delays in the project (Ansah \& Sorooshian, 2018)

\begin{tabular}{|c|c|c|c|c|}
\hline Delay type & $\begin{array}{c}\text { Payment } \\
\text { to the } \\
\text { employer }\end{array}$ & $\begin{array}{c}\text { Payment } \\
\text { to the } \\
\text { contractor }\end{array}$ & $\begin{array}{c}\text { Increase } \\
\text { time for the } \\
\text { contractor }\end{array}$ & Causes of delay \\
\hline Unforgivable & Yes & No & No & Contractor \\
\hline compensable & No & Yes & Yes & Another factor \\
\hline $\begin{array}{c}\text { Forgivable and } \\
\text { irreparable }\end{array}$ & No & No & Yes & Employer and contractor \\
\hline $\begin{array}{c}\text { Forgivable and } \\
\text { irreparable }\end{array}$ & No & No & Yes & Employer and other factors \\
\hline $\begin{array}{c}\text { Forgivable and } \\
\text { irreparable }\end{array}$ & No & No & Yes & Contractor and other agents \\
\hline $\begin{array}{c}\text { Forgivable and } \\
\text { irreparable }\end{array}$ & No & No & Yes & Employer, contractor and \\
other agents \\
\hline irreparable and
\end{tabular}

\subsection{Costs due to project delays}

Seyed-Hosseini et al. (2007) has introduced the following as project delay costs:

- Cost of late operation or lost profit

- Increase the cost of labor resources

- Cost of capital consumption consumed

- Possibility of uneconomicization of the project by postponing it

- Loss due to lack of job creation in the country

- Losses due to declining government revenue and social welfare of the people

- Cost of rising consumer resources

- The cost of renewing licenses and contracts

- Loss of competitive market

According to Williams (2013), in recent years, projects have faced more time constraints and the ability to deliver projects quickly has become an important growth factor in winning tenders. In tight-ended contracts, much emphasis is placed on transferring time risk to other contracts by the main contractor. This is usually done by considering heavy delay penalties.

\section{Case study}

In order to collect the data required for researching the organization under study, a questionnaire was used. In this regard, a questionnaire with a Likert scale of five options was designed and distributed among the stakeholders of research projects. The supervisors and advisors confirmed the validity of the research questionnaire questions and the reliability of those questions was also confirmed using Cronbach's alpha test. The statistical population consisting of the beneficiaries of the studied research projects has 74 members and the sample population has over 42 members. Service history, current position and job and level of familiarity with project management knowledge were introduced as moderating variables. In addition, SPSS computer software and various tests and statistical analyzes such as mean test have been used to examine the relationships between variables. 


\section{Conclusions}

The purpose of the present study is to prioritize the factors according to the stakeholders' views of research projects. The results of calculating the statistical mean of the effect of the factors are presented in Table 3. From the results of the analysis, it was concluded that internal factors with an average of 74.7 were more effective than external factors with an average of 66.2.

Also, among the intra-organizational factors, human factors with an average of 76.7 and human factors with project management with an average of 83.3 and system engineers with an average of 79.3 had the largest share in project delays.

Among the processes, the project management process and among the project management processes, the planning process group with an average of 84 and also the specialized field of project time management with an average of 84 have the most impact on project delays 77 had the greatest impact.

Table 2. Factors affecting the failure and delay of the project and the effectiveness of each factor

\begin{tabular}{|c|c|c|c|}
\hline Factor title & $\begin{array}{l}\text { Impact rate } \\
\quad(\text { of 100) }\end{array}$ & Factor title & $\begin{array}{l}\text { Impact rate } \\
(\text { of } 100)\end{array}$ \\
\hline $\begin{array}{l}\text { 1- Strategy and stability of senior } \\
\text { and middle management }\end{array}$ & 74 & $\begin{array}{l}\text { 27- How to manage project } \\
\text { procurement }\end{array}$ & 79 \\
\hline $\begin{array}{l}\text { 2- Support for senior and middle } \\
\text { management }\end{array}$ & 78 & 28- Feasibility process & 75 \\
\hline $\begin{array}{l}\text { 3- Professional competence of the } \\
\text { project manager }\end{array}$ & 84 & 29- Project approval process & 70 \\
\hline $\begin{array}{l}\text { 4- Behavioral competence of the } \\
\text { project manager }\end{array}$ & 83 & 30- Contract conclusion process & 76 \\
\hline $\begin{array}{l}\text { 5- Competence of project system } \\
\text { engineer }\end{array}$ & 79 & 31- Training process & 68 \\
\hline 6- Specialization of the project team & 76 & $\begin{array}{l}\text { 32- The process of selecting, } \\
\text { recruiting and employing employees }\end{array}$ & 65 \\
\hline 7- Motivation of the project team & 82 & 33- Knowledge management process & 74 \\
\hline 8- Productivity of the project team & 75 & $\begin{array}{l}\text { 34- Budget allocation process and } \\
\text { financial resources }\end{array}$ & 75 \\
\hline $\begin{array}{l}\text { 9- Allocation of sufficient human } \\
\text { resources }\end{array}$ & 67 & 35- Supply and purchase process & 77 \\
\hline $\begin{array}{l}\text { 10- Technical and technological } \\
\text { factors }\end{array}$ & 74 & $\begin{array}{l}\text { 36- Employee evaluation process and } \\
\text { financial payment }\end{array}$ & 76 \\
\hline $\begin{array}{l}\text { 11- Machinery, materials and } \\
\text { materials }\end{array}$ & 67 & $\begin{array}{l}\text { 37- The process of preparing and } \\
\text { approving maps and documents }\end{array}$ & 68 \\
\hline $\begin{array}{l}\text { 12-Organizational structure and } \\
\text { culture }\end{array}$ & 77 & $\begin{array}{l}\text { 38- Timely payment by the } \\
\text { customer/employer }\end{array}$ & 65 \\
\hline $\begin{array}{l}\text { 13- Existence of efficient } \\
\text { information system }\end{array}$ & 63 & $\begin{array}{l}\text { 39- Timely decision by the } \\
\text { client/employer }\end{array}$ & 65 \\
\hline $\begin{array}{l}\text { 14- Coordination of line and } \\
\text { headquarters }\end{array}$ & 72 & $\begin{array}{l}\text { 40- Fulfillment of obligations by the } \\
\text { client/employer }\end{array}$ & 67 \\
\hline 15- Position of project manager & 73 & 41- Customer / employer participation & 67 \\
\hline 16- Project planning process group & 84 & 42- Contractor's managerial ability & 72 \\
\hline $\begin{array}{l}\text { 17- Project monitoring and control } \\
\text { process group }\end{array}$ & 76 & 43-Technical ability of the contractor & 72 \\
\hline 18-Closing process group & 65 & $\begin{array}{l}\text { 44- Financial capacity of the } \\
\text { contractor }\end{array}$ & 69 \\
\hline 19- How to manage project integrity & 74 & $\begin{array}{l}\text { 45- Fulfillment of obligations by the } \\
\text { contractor }\end{array}$ & 74 \\
\hline 20- How to manage the project area & 78 & 46. Non-exclusive contractor & 63 \\
\hline 21- How to manage project time & 84 & 47- Supervisor performance & 73 \\
\hline 22- How to manage project costs & 76 & 48-Consultant performance & 69 \\
\hline 23- How to manage project quality & 73 & 49- Economic factors & 59 \\
\hline $\begin{array}{l}\text { 24- How to manage the human } \\
\text { resources of the project }\end{array}$ & 76 & 50- Political and social factors & 74 \\
\hline $\begin{array}{l}\text { 25- How to manage project } \\
\text { communications }\end{array}$ & 68 & $\begin{array}{l}\text { 51- Geographical and atmospheric } \\
\text { factors }\end{array}$ & 51 \\
\hline 26- How to manage project risk & 79 & 52- Legal factors and laws & 53 \\
\hline
\end{tabular}


In total, according to the results of the research, the 10 main factors affecting project delays are as follows:

1- The level of professional competence of the project manager (project management knowledge, experience, skills and ability of the project manager).

2- Project planning process (scope, time, cost, quality, human resources, communications, risk, procurement).

3- How to manage project time (correct estimation, development of real schedule, consideration of resources and capacities in scheduling).

4- The level of behavioral competence of the project manager (leadership, participation, creativity, determination, consultation, crisis resolution, calm, ethical principles, debatability, outcome).

5- The motivation of the project team (satisfaction, responsibility, sense of duty, teamwork spirit).

6- The level of expertise and skill of the project system engineer (in block design and determining the input and output of subsystems, system aggregation).

7- How to manage project procurement (estimating purchase time, identifying suppliers, planning and purchasing control).

8- How to manage project risk (identification, evaluation and planning of dealing with risks and bottlenecks).

9- The level of support of senior managers in allocating resources and permits and powers necessary for the success of the project.

10- How to manage the project area (determining the boundaries of the project, outputs and objectives of the project, breaking down macro-activities).

According to the results of the analysis of the most effective causes, problems and challenges related to improvement strategies, each of the above ten factors was examined and in order to reduce the impact of existing factors, the opinion of experts, various solutions and suggestions in areas related to research variables are used and presented in appendix 2 . The proposed proposals are executive and practical, and if appropriate measures are taken to implement them in the industry, the projects will be implemented more appropriately.

\section{References}

Agyekum-Mensah, G., \& Knight, A. D. (2017). The professionals' perspective on the causes of project delay in the construction industry. Engineering, Construction and Architectural Management.

Al-Momani, A. H. (2000). Construction delay: a quantitative analysis. International Journal of Project Management, 18(1), 51-59.

Ali, A. S., Smith, A., Pitt, M., \& Choon, C. H. (2007). CONTRACTORS'PERCEPTION OF FACTORS CONTRIBUTING TO PROJECT DELAY: CASE STUDIES OF COMMERCIAL PROJECTS IN KLANG VALLEY, MALAYSIA. Journal of Design and Built Environment, 7(1).

AlSehaimi, A., Koskela, L., \& Tzortzopoulos, P. (2013). Need for alternative research approaches in construction management: Case of delay studies. Journal of Management in Engineering, 29(4), 407-413.

Amandin, M. M., \& Kule, J. W. (2016). Project delays on cost overrun risks: A study of Gasabo district construction projects Kigali, Rwanda. ABC Journal of Advanced Research, 5(1), 21-34.

Ansah, R. H., \& Sorooshian, S. (2018). 4P delays in project management. Engineering, Construction and Architectural Management.

Artz, K. W., Norman, P. M., Hatfield, D. E., \& Cardinal, L. B. (2010). A longitudinal study of the impact of $\mathrm{R} \& \mathrm{D}$, patents, and product innovation on firm performance. Journal of product innovation management, 27(5), 725-740.

Asgari, M., Kheyroddin, A., \& Naderpour, H. (2017). A Proposal Model for Estimation of Project Success in Terms of Radial Based Neural Networks: A Case Study in Iran. Civil Engineering Journal, 3(10), 904-919.

Assaf, S. A., \& Al-Hejji, S. (2006). Causes of delay in large construction projects. International Journal of Project Management, 24(4), 349-357.

Attaran, M. (2004). Exploring the relationship between information technology and business process reengineering. Information \& management, 41(5), 585-596. 
Buss, A. H., \& Rosenblatt, M. J. (1997). Activity delay in stochastic project networks. Operations Research, 45(1), 126-139.

Chiu, B. W., \& Lai, J. H. (2017). Project delay: key electrical construction factors in Hong Kong. Journal of civil engineering and management, 23(7), 847-857.

Davis, K. (2017). An empirical investigation into different stakeholder groups perception of project success. International Journal of Project Management, 35(4), 604-617.

Dinakar, A. (2014). Delay analysis in construction project. International Journal of Emerging Technology and Advanced Engineering, 4(5), 784-788.

Doloi, H., Sawhney, A., \& Iyer, K. (2012). Structural equation model for investigating factors affecting delay in Indian construction projects. Construction Management and Economics, 30(10), 869884.

Dorji, L., Rai, S., Namgay, K., Pelden, T., \& Sunwar, I. (2020). Evaluation of Factors Causing Delays in Construction Projects in Bhutan. GNH Journal of Construction Technology and Management.

Durdyev, S., \& Hosseini, M. R. (2019). Causes of delays on construction projects: a comprehensive list. International Journal of Managing Projects in Business.

Elawi, G. S. A., Algahtany, M., \& Kashiwagi, D. (2016). Owners' perspective of factors contributing to project delay: case studies of road and bridge projects in Saudi Arabia. Procedia Engineering, $145,1402-1409$.

Engeström, Y. (2005). Developmental work research: Expanding activity theory in practice (Vol. 12): Lehmanns Media.

Fallahnejad, M. H. (2013). Delay causes in Iran gas pipeline projects. International Journal of Project Management, 31(1), 136-146.

Frimpong, Y., Oluwoye, J., \& Crawford, L. (2003). Causes of delay and cost overruns in construction of groundwater projects in a developing countries; Ghana as a case study. International Journal of Project Management, 21(5), 321-326.

Gebrehiwet, T., \& Luo, H. (2017). Analysis of delay impact on construction project based on RII and correlation coefficient: Empirical study. Procedia Engineering, 196, 366-374.

Gondia, A., Siam, A., El-Dakhakhni, W., \& Nassar, A. H. (2020). Machine learning algorithms for construction projects delay risk prediction. Journal of Construction Engineering and Management, 146(1), 04019085.

Guida, P. L., \& Sacco, G. (2019). A method for project schedule delay analysis. Computers \& Industrial Engineering, 128, 346-357.

Kabirifar, K., \& Mojtahedi, M. (2019). The impact of Engineering, Procurement and Construction (EPC) phases on project performance: A case of large-scale residential construction project. Buildings, 9(1), 15.

Lashgarara, F., Torabi, A., \& Omidi Najafabadi, M. (2016). Recognizing the Reasons for Success of Growth Enterprises at Agriculture Sector of Semnan Province, Iran. International Journal of Agricultural Management and Development, 6(4), 531-540.

León, H. C. M., \& Farris, J. A. (2011). Lean product development research: Current state and future directions. Engineering Management Journal, 23(1), 29-51.

Lindkvist, L. (2005). Knowledge communities and knowledge collectivities: A typology of knowledge work in groups. Journal of Management studies, 42(6), 1189-1210.

Mahamid, I., Bruland, A., \& Dmaidi, N. (2012). Causes of delay in road construction projects. Journal of Management in Engineering, 28(3), 300-310.

Prasad, K., Vasugi, V., Venkatesan, R., \& Bhat, N. (2019). Analysis of causes of delay in Indian construction projects and mitigation measures. Journal of Financial Management of Property and Construction.

Rashidi, K., Shabani, A., \& Saen, R. F. (2015). Using data envelopment analysis for estimating energy saving and undesirable output abatement: a case study in the Organization for Economic CoOperation and Development (OECD) countries. Journal of Cleaner Production, 105, 241-252.

Reams, R. R., Agrawal, D., Davis, M. B., Yoder, S., Odedina, F. T., Kumar, N., . . Soliman, K. F. (2009). Microarray comparison of prostate tumor gene expression in African-American and Caucasian American males: a pilot project study. Paper presented at the Infectious agents and cancer.

Sabzehparvar, M., \& Seyed-Hosseini, S. M. (2008). A mathematical model for the multi-mode resourceconstrained project scheduling problem with mode dependent time lags. The Journal of Supercomputing, 44(3), 257-273. 
Seyed-Hosseini, S. M., Sabzehparvar, M., \& Nouri, S. (2007). A Genetic algorithm and a model for the resource constrained project scheduling problem with multiple crushable modes. International Journal of Industrial Engineering \& Production Research, 18(3), 7-18.

Shabbab Al Hammadi, M. (2016). Study of delay factors in construction projects. International Advanced Research Journal in Science, Engineering and Technology, 3(4), 87-93.

Shaikh, A., Muree, M., \& Soomro, A. (2010). Identification of critical delay factors in construction. Sindh University Research Journal-SURJ (Science Series), 42(2).

Sharifi, M., Akram, A., Rafiee, S., \& Sabzehparvar, M. (2014). Planning and scheduling barley production mechanization project using the PERT network: case study Alborz province. Iranian Journal of Biosystems Engineering, 45(1), 11-22.

Silvius, A. G., \& Schipper, R. P. (2014). Sustainability in project management competencies: analyzing the competence gap of project managers. Journal of Human Resource and Sustainability Studies, 2014.

Singh, H., \& Williams, P. S. (2020). A Guide to the Project Management Body of Knowledge: PMBOK (®) Guide.

Sonenshein, S. (2010). We're changing - Or are we? Untangling the role of progressive, regressive, and stability narratives during strategic change implementation. Academy of Management Journal, 53(3), 477-512.

Sprecher, A., Kolisch, R., \& Drexl, A. (1995). Semi-active, active, and non-delay schedules for the resource-constrained project scheduling problem. European Journal of Operational Research, 80(1), 94-102.

Williams, T. (2003). Assessing extension of time delays on major projects. International Journal of Project Management, 21(1), 19-26.

Williams, T. M. (2013). Managing and modelling complex projects (Vol. 17): Springer.

Woodward, R. (2004). The organisation for economic cooperation and development: Global monitor. New Political Economy, 9(1), 113-127.

Yang, J.-B., \& Wei, P.-R. (2010). Causes of delay in the planning and design phases for construction projects. Journal of Architectural Engineering, 16(2), 80-83.

Zafar, M. W., Saud, S., \& Hou, F. (2019). The impact of globalization and financial development on environmental quality: evidence from selected countries in the Organization for Economic Cooperation and Development (OECD). Environmental Science and Pollution Research, 26(13), 13246-13262.

Zahedi, M., Akhavan, P., \& Naghdi Khanachah, S. (2020). Identifying the Key Barriers to Knowledge Management and Lessons Learned in the Project-Based Military Organizations. MILITARY MANAGEMENT QUARTERLY, 19(76), 29-68.

Zahedi, M. R., \& Khanachah, S. N. (2019). The impact of customer assisted knowledge production capacity on customer capital in a knowledge-based center. Annals of Management and Organization Research, 1(2), 107-121.

Zahedi, M. R., \& Khanachah, S. N. (2020). The effect of knowledge management processes on organizational innovation through intellectual capital development in Iranian industrial organizations. Journal of Science and Technology Policy Management.

Appendix 1. Factors affecting the failure and delay of the project extracted from research and references

\begin{tabular}{|c|c|c|c|}
\hline Factor title & Reference & Factor title & Reference \\
\hline $\begin{array}{l}\text { 1- Strategy and } \\
\text { stability of senior } \\
\text { and middle } \\
\text { management }\end{array}$ & $\begin{array}{l}\text { (Amandin \& Kule, 2016; } \\
\text { Ansah \& Sorooshian, 2018; } \\
\frac{\text { Singh \& Williams, 2020; }}{\text { Sonenshein, 2010; } T .} \\
\frac{\text { Williams, 2003; } \text { M. Zahedi }}{\text { et al., 2020) }}\end{array}$ & $\begin{array}{l}27-\text { How to } \\
\text { manage project } \\
\text { procurement }\end{array}$ & $\begin{array}{l}\frac{\text { (Ali et al., 2007; Attaran, }}{2004 ; \text { Dinakar, 2014; }} \\
\text { Engeström, 2005; Frimpong et } \\
\frac{\text { al., 2003; Prasad et al.., 2019; }}{\text { Sabzehparvar \& Seyed - }} \\
\frac{\text { Hosseini, 2008) }}{\text { Hos }}\end{array}$ \\
\hline $\begin{array}{l}\text { 2- Support for } \\
\text { senior and middle } \\
\text { management }\end{array}$ & $\begin{array}{l}\frac{\text { (Al-Momani, 2000; Attaran, }}{\text { 2004; Davis, 2017; } ; \text { T. M. }} \\
\frac{\text { Williams, 2013; M. Zahedi et }}{\underline{\text { al. }, 2020)}}\end{array}$ & $\begin{array}{c}\text { 28- Feasibility } \\
\text { process }\end{array}$ & $\begin{array}{l}\frac{\text { (Ali et al., 2007; Sabzehparvar }}{\text { \& Seyed-Hosseini, 2008; }} \\
\frac{\text { Sharifi et al., 2014; }}{\text { Sonenshein, 2010; } \text { T. Williams, }} \\
\text { 2003) }\end{array}$ \\
\hline
\end{tabular}




\begin{tabular}{|c|c|c|c|}
\hline Factor title & Reference & Factor title & Reference \\
\hline $\begin{array}{l}\text { 3-Professional } \\
\text { competence of the } \\
\text { project manager }\end{array}$ & $\begin{array}{l}\frac{\text { Assaf \& Al-Hejji, 2006; }}{\text { Chiu \& Lai, 2017; Davis, }} \\
\frac{\text { 2017; Dorji et al., 2020; }}{\text { Yang \& Wei, 2010; } \text { M. }} \\
\text { Zahedi et al., 2020) }\end{array}$ & $\begin{array}{c}\text { 29- Project } \\
\text { approval process }\end{array}$ & $\begin{array}{l}\frac{\text { Singh \& Williams, 2020; }}{\text { Sprecher et al., 1995; }} \text {. } \\
\frac{\text { Williams, 2003 } ; \text { T.M. }}{\text { Williams, 2013; Yang \& }} \\
\text { Wei, 2010) }\end{array}$ \\
\hline $\begin{array}{l}\text { 4- Behavioral } \\
\text { competence of the } \\
\text { project manager }\end{array}$ & $\begin{array}{l}\frac{\text { Singh \& Williams, 2020; }}{\text { Sprecher et al., 1995; } ; .} \\
\frac{\text { Williams, 2003; T.M. }}{\text { Williams, 2013; Yang \& Wei, }} \\
\text { 2010) }\end{array}$ & $\begin{array}{c}\text { 30- Contract } \\
\text { conclusion process }\end{array}$ & $\begin{array}{l}\frac{(\text { Al-Momani, 2000; }}{\text { Attaran, 2004; Davis, }} \\
\frac{2017 ;}{\text { T.M. Williams, }} \\
\underline{\text { 2013 } ; \frac{\text { M. Zahedi et al., }}{2020)}}\end{array}$ \\
\hline $\begin{array}{l}\text { 5- Competence of } \\
\text { project system } \\
\text { engineer }\end{array}$ & $\begin{array}{l}\frac{\text { (Agyekum-Mensah \& Knight, }}{2017} ; \text { Al-Momani, 2000; } ; \text { Artz } \\
\text { et al., 2010; Asgari et al., } \\
\text { 2017; Assaf \& Al-Hejii, 2006) }\end{array}$ & $\begin{array}{l}\text { 31- Training } \\
\text { process }\end{array}$ & $\begin{array}{l}\frac{\text { Singh \& Williams, 2020; }}{\text { Sprecher et al. }, 1995 ; T .} \\
\frac{\text { Williams, } 2003 ; T . M .}{\text { Williams, 2013; Yang \& }} \\
\text { Wei, 2010) }\end{array}$ \\
\hline $\begin{array}{l}\text { 6- Specialization of } \\
\text { the project team }\end{array}$ & $\begin{array}{c}\frac{\text { (Ali et al., 2007; Attaran, }}{\text { 2004; Dinakar, 2014; }} \\
\text { Engeström, 2005; Frimpong } \\
\text { et al., 2003; Prasad et al., } \\
\text { 2019; } \frac{\text { Sabzehparvar \& Seyed }-}{\text { Hosseini, 2008) }}\end{array}$ & $\begin{array}{l}\text { 32- The process of } \\
\text { selecting, } \\
\text { recruiting and } \\
\text { employing } \\
\text { employees }\end{array}$ & $\begin{array}{l}\frac{\text { (Ali et al., 2007; Sabzehparvar }}{\text { \& Seyed-Hosseini, 2008; }} \\
\frac{\text { Sharifi et al., 2014; }}{\underline{\text { Sonenshein, 2010 }} ; \text { T. Williams, }} \\
\underline{2003)}\end{array}$ \\
\hline $\begin{array}{c}\text { 7- Motivation of the } \\
\text { project team }\end{array}$ & 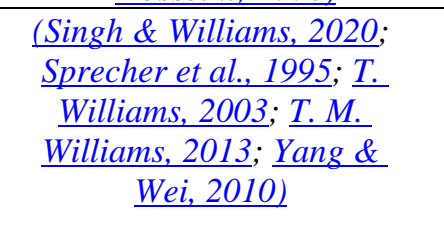 & $\begin{array}{l}\text { 33- Knowledge } \\
\text { management } \\
\text { process }\end{array}$ & $\begin{array}{l}\frac{\text { (Ali et al., 2007; Attaran, }}{2004 ;} ; \text { Dinakar, 2014; } \\
\text { Engeström, 2005; Frimpong et } \\
\frac{\text { al., 2003 } ; \text { Prasad et al., 2019); }}{\text { Sabzehparvar \& Seyed - }} \\
\text { Hosseini, 2008) }\end{array}$ \\
\hline $\begin{array}{l}\text { 8-Productivity of } \\
\text { the project team }\end{array}$ & $\begin{array}{c}\text { (Ali et al., 2007; } \\
\frac{\text { Sabzehparvar \& Seyed- }}{\text { Hosseini, 2008; } ; \text { Sharifi et al., }} \\
\frac{\text { 2014 }}{\frac{\text { Sonenshein, 2010 }}{\text { Williams, 2003) }} ; \underline{T}}\end{array}$ & $\begin{array}{l}\text { 34- Budget } \\
\text { allocation process } \\
\text { and financial } \\
\text { resources }\end{array}$ & $\begin{array}{c}\text { (Ali et al., 2007; } \\
\text { Sabzehparvar \& Seyed- } \\
\text { Hosseini, 2008; Sharifi et } \\
\frac{\text { al., 2014; Sonenshein, }}{\text { 2010; } \text { T. Williams, 2003) }}\end{array}$ \\
\hline $\begin{array}{l}\text { 9- Allocation of } \\
\text { sufficient human } \\
\text { resources }\end{array}$ & $\begin{array}{l}\frac{\text { (Agyekum-Mensah \& Knight, }}{\text { 2017; Asgari et al., 2017; }} \\
\text { Guida \& Sacco, 2019; } \\
\frac{\text { Sonenshein, 2010; M. Zahedi }}{\text { et al., 2020) }}\end{array}$ & $\begin{array}{c}\text { 35- Supply and } \\
\text { purchase process }\end{array}$ & $\begin{array}{l}\frac{\text { Mahamid et al., 2012; Seyed- }}{\text { Hosseini et al., 2007; }} \\
\frac{\text { Sonenshein, 2010; Sprecher et }}{\text { al., 1995) }}\end{array}$ \\
\hline $\begin{array}{l}\text { 10- Technical and } \\
\text { technological } \\
\text { factors }\end{array}$ & $\begin{array}{l}\text { (Mahamid et al., 2012; Seyed- } \\
\frac{\text { Hosseini et al., 2007; }}{\text { Sonenshein, 2010; Sprecher }} \\
\text { et al., 1995) }\end{array}$ & $\begin{array}{c}\text { 36- Employee } \\
\text { evaluation process } \\
\text { and financial } \\
\text { payment }\end{array}$ & $\begin{array}{l}\text { (Lindkvist, 2005; } \\
\underline{\text { Hammadi, 2016) }}\end{array}$ \\
\hline $\begin{array}{l}\text { 11- Machinery, } \\
\text { materials and } \\
\text { materials }\end{array}$ & $\begin{array}{l}\frac{\text { (Singh \& Williams, 2020; }}{\text { Sprecher et al., 1995; }} \text {. } \\
\frac{\text { Williams, 2003; T.M. }}{\text { Williams, 2013; Yang \& }} \\
\text { Wei, 2010) }\end{array}$ & $\begin{array}{l}\text { 37- The process of } \\
\text { preparing and } \\
\text { approving maps } \\
\text { and documents }\end{array}$ & $\begin{array}{l}\text { (Sabzehparvar \& Seyed- } \\
\text { Hosseini, 2008) }\end{array}$ \\
\hline $\begin{array}{l}\text { 12- Organizational } \\
\text { structure and } \\
\text { culture }\end{array}$ & $\begin{array}{l}\frac{\text { (Ali et al., 2007; Attaran, }}{\text { 2004; Dinakar, 2014; }} \\
\text { Engeström, 2005; } \\
\frac{\text { Frimpong et al., 2003; }}{\text { Prasad et al., 2019; }} \\
\frac{\text { Sabzehparvar \& Seyed- }}{\text { Hosseini, 2008) }}\end{array}$ & $\begin{array}{l}\text { 38- Timely } \\
\text { payment by the } \\
\text { customer / } \\
\text { employer }\end{array}$ & $\begin{array}{l}\frac{(\text { Singh \& Williams, 2020; }}{\text { Sprecher et al., 1995; } ; .} \\
\frac{\text { Williams, 2003 } ; \text { T.M. }}{\text { Williams, 2013 } ; \underline{\text { Yang \& }}} \\
\underline{\text { Wei, 2010) }}\end{array}$ \\
\hline $\begin{array}{l}\text { 13- Existence of } \\
\text { efficient information } \\
\text { system }\end{array}$ & 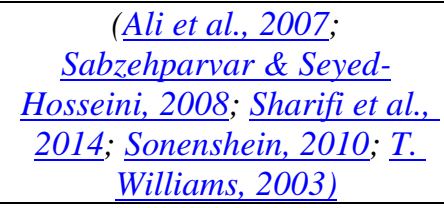 & $\begin{array}{c}\text { 39- Timely } \\
\text { decision by the } \\
\text { client / employer }\end{array}$ & $\begin{array}{l}\frac{\text { (Agyekum-Mensah \& Knight, }}{\text { 2017; Asgari et al., 2017; }} \\
\text { Guida \& Sacco, 2019; } \\
\frac{\text { Sonenshein, 2010; M. Zahedi }}{\text { et al., 2020) }}\end{array}$ \\
\hline $\begin{array}{l}\text { 14- Coordination of } \\
\text { line and } \\
\text { headquarters }\end{array}$ & $\begin{array}{l}\frac{\text { (Mahamid et al., 2012; Seyed- }}{\text { Hosseini et al., 2007; }} \\
\frac{\text { Sonenshein, 2010; Sprecher }}{\text { et al., 1995) }}\end{array}$ & $\begin{array}{l}40 \text { - Fulfillment of } \\
\text { obligations by the } \\
\text { client / employer }\end{array}$ & $\begin{array}{c}\frac{\text { (Ali et al., 2007 }}{2004 ; \text { Dinakar, 2014 } ;} \\
\text { Engeström, 2005; } ; \text { Frimpong et } \\
\text { al., 2003; Prasad et al., 2019; }\end{array}$ \\
\hline
\end{tabular}




\begin{tabular}{|c|c|c|c|}
\hline Factor title & Reference & Factor title & Reference \\
\hline & & & $\frac{\text { Sabzehparvar \& Seyed- }}{\text { Hosseini, 2008) }}$ \\
\hline $\begin{array}{c}\text { 15- Position of } \\
\text { project manager }\end{array}$ & $\begin{array}{l}\text { (Buss \& Rosenblatt, 1997; } \\
\frac{\text { Seyed-Hosseini et al., 2007; }}{\text { Sprecher et al., 1995) }}\end{array}$ & $\begin{array}{l}\text { 41- Customer / } \\
\text { employer } \\
\text { participation }\end{array}$ & $\frac{\text { (Chiu \& Lai, 2017; Dinakar, }}{\frac{\text { 2014; }}{\text { Khanachah, 2019) }}}$ \\
\hline $\begin{array}{l}\text { 16- Project planning } \\
\text { process group }\end{array}$ & $\begin{array}{c}\begin{array}{c}\text { Ali et al., 2007; } \\
\text { Sabzehparvar \& Seyed- }\end{array} \\
\frac{\text { Hosseini, 2008; Sharifi et al., }}{\text { 2014 } ;} ; \underline{\text { Sonenshein, 2010 } ; \underline{T .}} \\
\text { Williams, 2003) }\end{array}$ & $\begin{array}{l}\text { 42- Contractor's } \\
\text { managerial ability }\end{array}$ & $\begin{array}{l}\frac{\text { (Mahamid et al., 2012; }}{\text { Seyed- }} \\
\frac{\text { Hosseini et al., 2007; }}{\text { Sonenshein, 2010; Sprecher et }} \\
\underline{\text { al., 1995) }}\end{array}$ \\
\hline $\begin{array}{l}\text { 17- Project } \\
\text { monitoring and } \\
\text { control process } \\
\text { group }\end{array}$ & $\begin{array}{l}\frac{\text { Agyekum-Mensah \& Knight, }}{\text { 2017; Asgari et al. } 2017 ;} \\
\text { Guida \& Sacco, 2019; } \\
\frac{\text { Sonenshein, 2010; M. Zahedi }}{\text { et al., 2020) }}\end{array}$ & $\begin{array}{l}\text { 43- Technical } \\
\text { ability of the } \\
\text { contractor }\end{array}$ & $\begin{array}{l}\frac{\text { (Agyekum-Mensah \& Knight, }}{\text { 2017; Asgari et al., 2017; }} \\
\text { Guida \& Sacco, 2019; } \\
\frac{\text { Sonenshein, 2010; M. Zahedi }}{\text { et al., 2020) }}\end{array}$ \\
\hline $\begin{array}{l}\text { 18-Closing process } \\
\text { group }\end{array}$ & $\begin{array}{c}\frac{\text { (Ali et al., 2007; }}{\text { Sabzehparvar \& Seyed- }} \\
\frac{\text { Hosseini, 2008; } ; \text { Sharifi et al., }}{\underline{\text { 2014 }} ; \frac{\text { Sonenshein, 2010 }}{\text { Williams, 2003) }}}\end{array}$ & $\begin{array}{l}\text { 44- The financial } \\
\text { capacity of the } \\
\text { contractor }\end{array}$ & $\begin{array}{c}\frac{(\text { Ali et al., 2007; Attaran, }}{2004 ;} ; \text { Dinakar, 2014 } ; \\
\frac{\text { Engeström, 2005; Frimpong et }}{\text { al., 2003 } ; \text { Prasad et al., 2019) }} \\
\frac{\text { Sabzehparvar \& Seyed - }}{\text { Hosseini, 2008) }}\end{array}$ \\
\hline $\begin{array}{l}\text { 19- How to manage } \\
\text { project integrity }\end{array}$ & $\begin{array}{l}\text { (Amandin \& Kule, 2016; } \\
\frac{\text { Ansah \& Sorooshian, 2018; }}{\text { Singh \& Williams, 2020; }} \\
\frac{\text { Sonenshein, 2010; T. }}{\text { Williams, 2003 } ; \underline{\text { M. Zahedi et }}} \\
\underline{\text { al. } 2020)}\end{array}$ & $\begin{array}{l}\text { 45- Fulfillment of } \\
\text { obligations by the } \\
\text { contractor }\end{array}$ & $\begin{array}{l}\frac{\text { Mahamid et al., 2012; Seyed- }}{\text { Hosseini et al., 2007; }} \\
\frac{\text { Sonenshein, 2010; Sprecher et }}{\text { al., 1995) }}\end{array}$ \\
\hline $\begin{array}{l}\text { 20- How to manage } \\
\text { the project area }\end{array}$ & $\begin{array}{l}\frac{\text { (Mahamid et al., 2012; Seyed- }}{\text { Hosseini et al., 2007; }} \\
\text { Sonenshein, 2010; Sprecher } \\
\text { et al., 1995) }\end{array}$ & $\begin{array}{l}\text { 46- Non-exclusive } \\
\text { contractor }\end{array}$ & $\frac{\text { (Sabzehparvar \& Seyed- }}{\underline{\text { Hosseini, 2008) }}}$ \\
\hline $\begin{array}{l}\text { 21- How to manage } \\
\text { project time }\end{array}$ & $\begin{array}{c}\text { (Ali et al., 2007; } \\
\frac{\text { Sabzehparvar \& Seyed- }}{\text { Hosseini, 2008; Sharifi et }} \\
\frac{\text { al., 2014; Sonenshein, }}{2010 ; \text { T. Williams, 2003) }}\end{array}$ & $\begin{array}{l}\text { 47- Supervisor } \\
\text { performance }\end{array}$ & $\begin{array}{l}\frac{\text { (Ali et al., 2007; Sabzehparvar }}{\text { \& Seyed-Hosseini, 2008; }} \\
\frac{\text { Sharifi et al., 2014; }}{\text { Sonenshein, 2010; }} \\
\frac{\text { 2003) }}{\text { S. Williams, }}\end{array}$ \\
\hline $\begin{array}{c}\text { 22- How to manage } \\
\text { project costs }\end{array}$ & $\begin{array}{l}\frac{(\text { Agyekum-Mensah \& }}{\text { Knight, 2017; Asgari et al., }} \\
\frac{2017 ; \text { Guida \& Sacco, }}{\text { 2019; Sonenshein, 2010 } ;} ; \underline{\text { Mahedi et al., 2020) }}\end{array}$ & $\begin{array}{l}\text { 48-Consultant } \\
\text { performance }\end{array}$ & $\begin{array}{l}\frac{\text { (Ali et al., 2007; }}{\text { \&abzehparvar }} \\
\frac{\text { Seyed-Hosseini, 2008; }}{\text { Sharifi et al., 2014; }} \\
\frac{\text { Sonenshein, 2010; }}{2003)} \text { T. Williams, }\end{array}$ \\
\hline $\begin{array}{c}\text { 23- How to manage } \\
\text { project quality }\end{array}$ & $\begin{array}{c}\begin{array}{c}\text { (Ali et al., 2007; } \\
\text { Sabzehparvar \& Seyed- }\end{array} \\
\frac{\text { Hosseini, 2008 } ; \text { Sharifi et al., }}{\text { 2014 } ;} ; \underline{\text { Sonenshein, 2010 }} ; \underline{\text { Williams, 2003) }}\end{array}$ & $\begin{array}{l}\text { 49- Economic } \\
\text { factors }\end{array}$ & $\begin{array}{l}\frac{\text { (Agyekum-Mensah \& Knight, }}{\text { 2017; Asgari et al., 2017; }} \\
\text { Guida \& Sacco, 2019; } \\
\frac{\text { Sonenshein, 2010; M. Zahedi }}{\text { et al., 2020) }}\end{array}$ \\
\hline $\begin{array}{l}\text { 24- How to manage } \\
\text { the human resources } \\
\text { of the project }\end{array}$ & 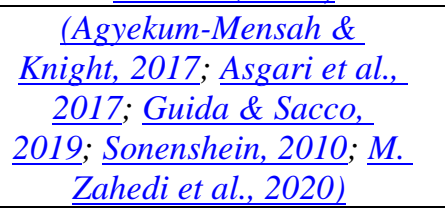 & $\begin{array}{l}\text { 50- Political and } \\
\text { social factors }\end{array}$ & $\begin{array}{l}\text { (Ali et al., 2007; Sabzehparvar } \\
\text { \& Seyed-Hosseini, 2008; } \\
\frac{\text { Sharifi et al., 2014; }}{\text { Sonenshein, 2010; }} \\
\text { 2003) }\end{array}$ \\
\hline $\begin{array}{c}\text { 25- How to manage } \\
\text { project } \\
\text { communications }\end{array}$ & $\begin{array}{c}\frac{(\text { Amandin \& Kule, 2016; }}{\text { Ansah \& Sorooshian, 2018; }} ; \\
\frac{\text { Singh \& Williams, 2020; }}{\text { Sonenshein, 2010; T. }} \\
\frac{\text { Williams, 2003 } ; \text { M. Zahedi et }}{\text { al., 2020) }}\end{array}$ & $\begin{array}{l}\text { 51-Geographical } \\
\text { and atmospheric } \\
\text { factors }\end{array}$ & $\begin{array}{l}\frac{\text { (Agyekum-Mensah \& Knight, }}{\text { 2017 } ; \text { Asgari et al., 2017; }} \\
\text { Guida \& Sacco, 2019; } \\
\frac{\text { Sonenshein, 2010; M. Zahedi }}{\text { et al., 2020) }}\end{array}$ \\
\hline $\begin{array}{l}\text { 26- How to manage } \\
\text { project risk }\end{array}$ & $\begin{array}{l}\frac{\text { Singh \& Williams, 2020; }}{\text { Sprecher et al., 1995; }} ; . \\
\text { Williams, 2003; T.M. }\end{array}$ & $\begin{array}{l}\text { 52- Legal factors } \\
\text { and laws }\end{array}$ & $\begin{array}{c}\frac{\text { Ali et al., 2007; Sabzehparvar }}{\text { \& Seyed-Hosseini, 2008; }} \\
\text { Sharifi et al., 2014; }\end{array}$ \\
\hline
\end{tabular}




\begin{tabular}{|c|c||c|c|}
\hline Factor title & Reference & Factor title & Reference \\
\hline & $\frac{\text { Williams, 2013; Yang \& }}{\text { Wei, 2010) }}$ & & $\frac{\text { Sonenshein, 2010; } \text { T. Williams, }}{2003)}$ \\
\hline
\end{tabular}

Appendix 2. Summary of problems and suggested solutions

\begin{tabular}{|c|c|c|c|}
\hline Row & Factor title & Existing problems & Improvement strategies \\
\hline 1 & $\begin{array}{l}\text { Professional } \\
\text { competence of } \\
\text { the project } \\
\text { manager }\end{array}$ & $\begin{array}{l}\text { - Selection of project manager } \\
\text { - Selection parameters } \\
\text { - Lack of knowledge of industry } \\
\text { managers about project } \\
\text { management knowledge } \\
\text { - Lack of attention to the } \\
\text { professional, behavioral and } \\
\text { conceptual competencies of the } \\
\text { project manager } \\
\text { - Lack of job description and } \\
\text { conditions for obtaining a job } \\
\text {-Lack of supervision of the } \\
\text { research institute on the selection } \\
\text { of project managers }\end{array}$ & $\begin{array}{l}\text { Considering the project management unit } \\
\text { (PMO) in the industry for planning, } \\
\text { developing models, developing training } \\
\text { topics, monitoring, evaluating and selecting } \\
\text { project managers. Due to the expansion of the } \\
\text { structure of the radar industry and its } \\
\text { transformation into the Radra Industries } \\
\text { Group, it is better for the mentioned unit to } \\
\text { operate directly under the supervision of the } \\
\text { group manager. } \\
\text { - Classification of project managers in levels } \\
\text { A to F, whose levels A to D are based on the } \\
\text { ICB model and competency framework of } \\
\text { project managers approved by the field of } \\
\text { industrial excellence - Project Management } \\
\text { Development Group of Defense Industries } \\
\text { Training and Research Institute, and levels E } \\
\text { and F are appropriate. The current } \\
\text { knowledge status of industry project } \\
\text { managers is defined as the minimum } \\
\text { knowledge required. } \\
\text { - Develop a system for promoting project } \\
\text { managers in a similar way and in parallel } \\
\text { with the system for promoting researchers } \\
\text { and assigning an organizational position of } \\
\text { 14 to } 17 \text { to project managers at levels D to A } \\
\text { and determining the minimum salary received } \\
\text { at each level so that the necessary and } \\
\text { sufficient attractiveness for growth and } \\
\text { promotion for individuals Create. It should be } \\
\text { noted that these benefits only apply to people } \\
\text { who work as project managers. } \\
\text { - Establishing correspondence between } \\
\text { project managers of different levels with } \\
\text { existing levels of future research projects. If } \\
\text { there is a gap between the level of project } \\
\text { managers and the levelofprojects, the person } \\
\text { can be appointed as a project manager, but } \\
\text { the benefits received by the person will be } \\
\text { equal to the existing level of project manager. }\end{array}$ \\
\hline 2 & $\begin{array}{c}\text { Behavioral } \\
\text { competence of }\end{array}$ & $\begin{array}{l}\text { - Selection of project manager } \\
\text { - Selection parameters } \\
\text { - Lack of knowledge of industry } \\
\text { managers about project } \\
\text { management knowledge } \\
\text { - Lack of attention to the } \\
\text { professional, behavioral and } \\
\text { conceptual competencies of the } \\
\text { project manager } \\
\text { - Lack of job description and } \\
\text { conditions for obtaining a job } \\
\text { - Lack of supervision of the } \\
\text { research institute on the selection } \\
\text { of project managers } \\
\text { - Training project managers } \\
\text { - Do not use students and } \\
\text { graduates of project management }\end{array}$ & $\begin{array}{l}\text { - Granting project management certification } \\
\text { to people who are at different levels or are } \\
\text { promoted to higher levels by the Project } \\
\text { Management Development Group } \\
\text { - Development of training courses in the } \\
\text { areas of professional, behavioral and } \\
\text { conceptual competence of project managers } \\
\text { based on ICB-defined topics and training } \\
\text { planning based on current levels of project } \\
\text { managers and their training needs. } \\
\text { - Using the method of student-teacher and } \\
\text { workshop courses to improve the quality of } \\
\text { learning. } \\
\text { - Holding visits to successful national } \\
\text { projects and using the experiences of } \\
\text { domestic and foreign project managers as a } \\
\text { seminar. }\end{array}$ \\
\hline
\end{tabular}




\begin{tabular}{|c|c|c|c|}
\hline Row & Factor title & Existing problems & Improvement strategies \\
\hline & $\begin{array}{l}\text { the project } \\
\text { manager }\end{array}$ & 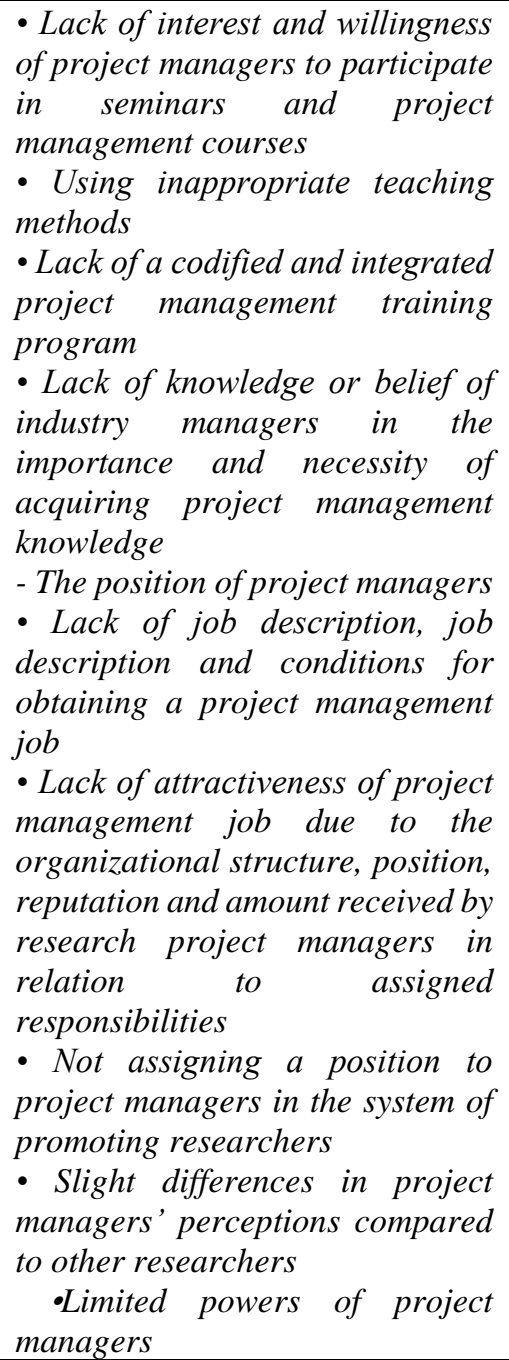 & $\begin{array}{l}\text {-Collecting and compiling native models of } \\
\text { nine areas of project management and } \\
\text { requiring project managers to implement } \\
\text { models. }\end{array}$ \\
\hline \multirow[t]{2}{*}{3} & \multirow[t]{2}{*}{$\begin{array}{l}\text { Competence of } \\
\text { a system } \\
\text { engineer }\end{array}$} & 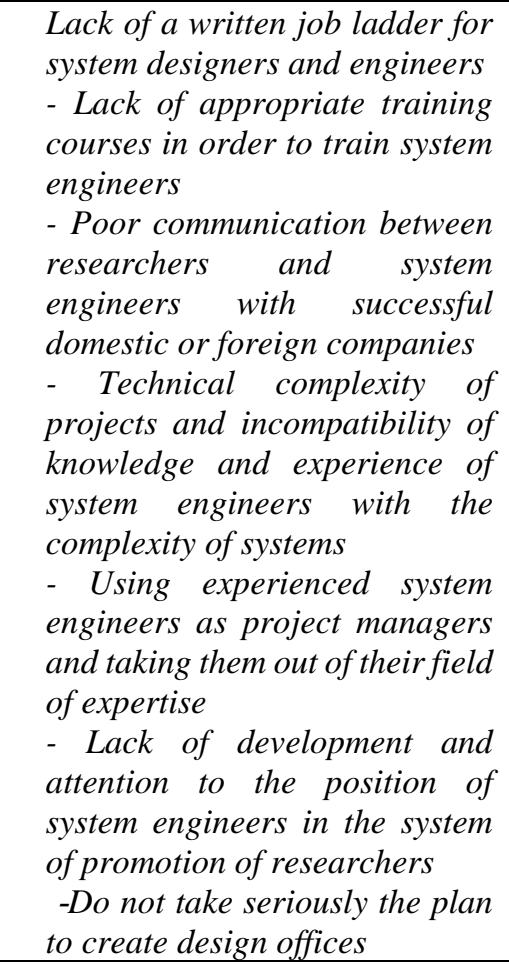 & $\begin{array}{l}\text { - Taking seriously the plan to create design } \\
\text { offices and implement it as a pilot in one of } \\
\text { the industries and eliminate the } \\
\text { shortcomings and problems of the plan } \\
\text { - Development of training courses required } \\
\text { by system engineers } \\
\text { - More interaction with successful domestic } \\
\text { and foreign companies and organizations } \\
\text { - Paying attention to international } \\
\text { standards in the field of system engineering } \\
\text { Assigning a suitable organizational } \\
\text { position to system engineers in order for } \\
\text { them to benefit from the benefits of the } \\
\text { position and motivate them for deep and } \\
\text { specialized work } \\
\text {-Carrying out joint projects with countries } \\
\text { with system engineering knowledge and } \\
\text { transferring their experiences through the } \\
\text { work and activities of the company's } \\
\text { specialists in foreign companies. }\end{array}$ \\
\hline & & $\begin{array}{l}\text { - Weakness in the system of } \\
\text { promotion of researchers } \\
\text { - Weakness in the payment } \\
\text { system and motivational factors }\end{array}$ & $\begin{array}{l}\text { - Improving the payment system in order to } \\
\text { make it fairer and have a greater impact on } \\
\text { the efficiency and work efficiency of people } \\
\text { in their total income }\end{array}$ \\
\hline
\end{tabular}




\begin{tabular}{|c|c|c|c|}
\hline Row & Factor title & Existing problems & Improvement strategies \\
\hline 4 & $\begin{array}{c}\text { Project team } \\
\text { motivation }\end{array}$ & $\begin{array}{l}\text { - Weakness in the system of } \\
\text { evaluation and job promotion } \\
\text { - Weakness in the distribution } \\
\text { system of welfare services } \\
\text {-Weakness in the education } \\
\text { system }\end{array}$ & $\begin{array}{l}\text { - Modify the system of promotion of } \\
\text { researchers and the method of promotion } \\
\text { and obtaining points by researchers so that } \\
\text { a clear definition of research and research } \\
\text { activity and research output is done. } \\
\text { - Special attention to performing } \\
\text { specialized work and engineering design } \\
\text { and recognizing and labeling designers } \\
\text { based on their technical and specialized } \\
\text { field. } \\
\text { - Development of job ladder and job } \\
\text { description of newcomers based on job } \\
\text { ladder } \\
\text {-Paying special attention to the issue of } \\
\text { training and learning of specialists and } \\
\text { compiling comprehensive training courses } \\
\text { based on technology architecture plan }\end{array}$ \\
\hline 5 & $\begin{array}{l}\text { Support of the } \\
\text { senior } \\
\text { manager }\end{array}$ & $\begin{array}{l}\text { - Inadequate prioritization of } \\
\text { projects } \\
\text { - Weakness in the project } \\
\text { approval process } \\
\text { - Lack of attention to strategic } \\
\text { planning and long-term future } \\
\text { of the company } \\
\text {-Lack of attention to project } \\
\text { portfolio management }\end{array}$ & $\begin{array}{l}\text { - Develop a strategic plan of the } \\
\text { organization and pay more attention to the } \\
\text { future and future products of the } \\
\text { organization } \\
\text { Establishment of a project management } \\
\text { office in order to properly allocate } \\
\text { resources and pay attention to project } \\
\text { portfolio management } \\
\text {-Coordinating the project portfolio with } \\
\text { the long-term strategy of the organization } \\
\text { in the project approval stage }\end{array}$ \\
\hline 6 & $\begin{array}{c}\text { Project } \\
\text { planning }\end{array}$ & 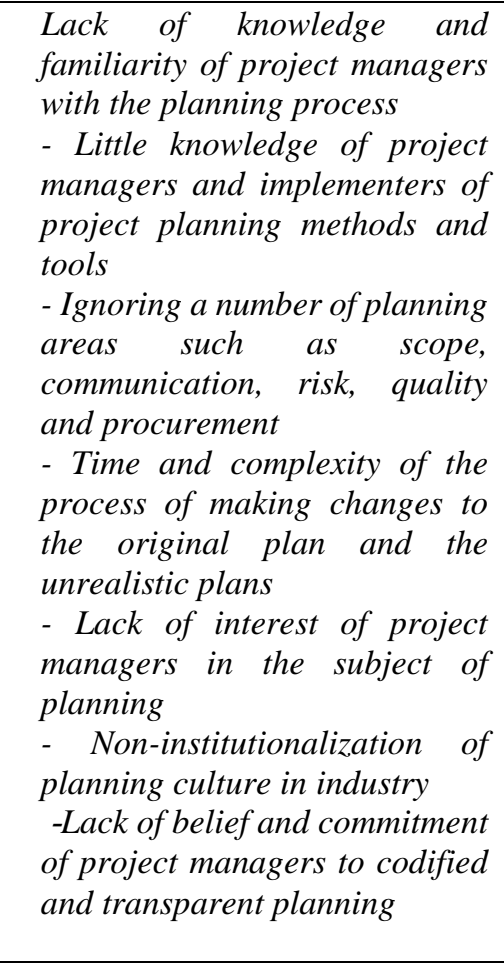 & $\begin{array}{l}\text { - Development of project management plan } \\
\text { (including management plan of } 8 \\
\text { specialized areas of project management) } \\
\text { at the beginning of the project as one of the } \\
\text { three main project documents } \\
\text { Obligation of the project manager to follow } \\
\text { the project management plan } \\
\text { - Preparing models for developing a } \\
\text { project management plan and planning its } \\
\text { various areas by the research institute or } \\
\text { project management office } \\
\text { - Develop a program and process of project } \\
\text { change management and reduce decision- } \\
\text { making time regarding changes } \\
\text { - Special attention of senior managers to } \\
\text { the issue of planning in order to model and } \\
\text { institutionalize the culture of planning in } \\
\text { the industry } \\
\text { - Increasing the competence of project } \\
\text { managers by holding appropriate training } \\
\text { courses } \\
\text {-Evaluate and select middle managers } \\
\text { based on their commitment to the subject of } \\
\text { planning }\end{array}$ \\
\hline & & $\begin{array}{l}\text { - Lack of familiarity of project } \\
\text { managers with the literature and } \\
\text { knowledge of project area } \\
\text { management } \\
\text { - Inattention of project managers } \\
\text { to the field of area management } \\
\text { - Defects in the models prepared } \\
\text { by the research institute and } \\
\text { purely technical vision }\end{array}$ & $\begin{array}{l}\text { - Training project managers in order to get } \\
\text { acquainted with the knowledge of project } \\
\text { management and the importance of paying } \\
\text { attention to the field of area management } \\
\text { - Development of models for preparing the } \\
\text { project charter, statement of scope and } \\
\text { structure of project failure } \\
\text { - Paying attention to the approach of } \\
\text { formulating the structure of work failure } \\
\text { according to the deliverable items of the } \\
\text { project }\end{array}$ \\
\hline
\end{tabular}




\begin{tabular}{|c|c|c|c|}
\hline Row & Factor title & Existing problems & Improvement strategies \\
\hline 7 & $\begin{array}{l}\text { Project scope } \\
\text { management }\end{array}$ & $\begin{array}{l}\text {-Limiting project managers to the } \\
\text { existing model by the research } \\
\text { institute }\end{array}$ & $\begin{array}{l}\text { - Accelerate the review process and } \\
\text { approve changes in the area } \\
\text { - Requiring project managers to prepare } \\
\text { and submit a statement of scope and } \\
\text { structure of work failure before } \\
\text { formulating project activities } \\
\text {-Leaving the project manager free to } \\
\text { formulate the project work failure structure } \\
\text { based on the project scope statement and } \\
\text { deliverables }\end{array}$ \\
\hline 8 & $\begin{array}{l}\text { Project time } \\
\text { management }\end{array}$ & 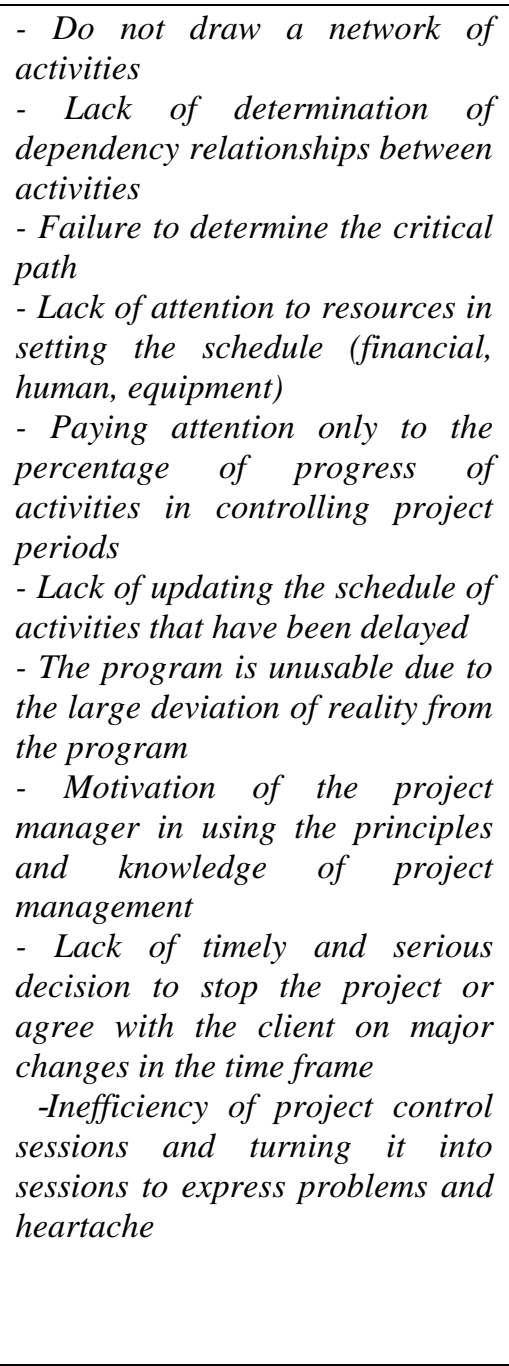 & $\begin{array}{l}\text { - Holding a training project planning and } \\
\text { control training workshop at the level of } \\
\text { current and future project managers } \\
\text { - Requiring project managers to prepare a list } \\
\text { of activities based on the project failure } \\
\text { structure } \\
\text { - Use of existing software such as Microsoft } \\
\text { Project or Primavera to facilitate the network } \\
\text { drawing process and scheduling of activities } \\
\text { - Doing phase-by-phase planning for projects } \\
\text { with high complexity (currently in a number } \\
\text { of projects this method is underway) } \\
\text { - Paying attention to the time frame of the } \\
\text { whole project in scheduling activities and } \\
\text { determining the project task in case of } \\
\text { excessive deviation of the initial plan from the } \\
\text { time of project completion } \\
\text { - Allocating resources to project activities } \\
\text { and correcting the project schedule } \\
\text { according to the allocated resources } \\
\text { - Using the network platform to update } \\
\text { information on the progress of activities and } \\
\text { changes in the schedule } \\
\text { - Using the available software to predict the } \\
\text { completion status of the project based on real } \\
\text { conditions } \\
\text { - Paying special attention to the critical path } \\
\text { of the project and making quick decisions } \\
\text { regarding the delay of critical activities } \\
\text {-Special attention of senior managers to } \\
\text { Gontrol and monitor the project based on } \\
\text { instead of receiving scattered and verbal } \\
\text { information }\end{array}$ \\
\hline 9 & $\begin{array}{c}\text { Project } \\
\text { Procurement } \\
\text { Management }\end{array}$ & $\begin{array}{l}\text { - The government structure of the } \\
\text { company and the existence of } \\
\text { strict rules and regulations on the } \\
\text { purchase and cost of projects } \\
\text { - Existence of many decision } \\
\text { makers in making purchases } \\
\text { - Priority of allocating budget and } \\
\text { liquidity to production projects } \\
\text { and financial problems of } \\
\text { research projects } \\
\text { Lack of familiarity of project } \\
\text { managers with the field of } \\
\text { knowledge of project procurement } \\
\text { management } \\
\text {-Lack of proper planning and } \\
\text { forecasting of the date of receipt of } \\
\text { goods }\end{array}$ & $\begin{array}{l}\text { Granting the necessary authority to project } \\
\text { managers to purchase the necessary items } \\
\text { (items that by law do not require price inquiry } \\
\text { and bidding) } \\
\text { - Eliminate a number of signatures required } \\
\text { for the purchase request form in research } \\
\text { projects in order to expedite the delivery of } \\
\text { forms to the Procurement Unit } \\
\text { - Allocation of manpower in charge of } \\
\text { procurement to large projects (resident) to } \\
\text { facilitate procurement and follow up and } \\
\text { report on the latest status of procurement } \\
\text { - Prepare a complete database of purchase } \\
\text { requests to enter the initial time estimate } \\
\text { information andforecast the date of receipt of } \\
\text { goods during the project and real-time } \\
\text { information of receipt of goods, to improve } \\
\text { the purchase process and more accurate }\end{array}$ \\
\hline
\end{tabular}




\begin{tabular}{|c|c|c|c|}
\hline Row & Factor title & Existing problems & Improvement strategies \\
\hline & & & $\begin{array}{l}\text { estimation of the time period of subsequent } \\
\text { similar purchases. } \\
\text { - Comprehensive evaluation of contractors } \\
\text { and updating of contractors information by } \\
\text { the Procurement Unit } \\
\text {-Paying attention to the issue of sanctions } \\
\text { and the possibility of not having access to } \\
\text { resources when designing and predicting } \\
\text { parallel roads }\end{array}$ \\
\hline 10 & $\begin{array}{c}\text { Project risk } \\
\text { management }\end{array}$ & $\begin{array}{l}\text { - Project media's inattention to the } \\
\text { field of risk management, despite } \\
\text { its great importance in research } \\
\text { projects } \\
\text { - Project managers are not } \\
\text { familiar with the knowledge of the } \\
\text { field of risk management } \\
\text { Lack of knowledge of project } \\
\text { managers about tools, methods } \\
\text { and models in this field }\end{array}$ & $\begin{array}{l}\text { - Implementation of project risk management } \\
\text { processes based on PMBOK model: } \\
\text { - Risk identification } \\
\text { - Qualitative risk analysis } \\
\text { - Quantitative risk analysis } \\
\text { - Develop a risk response plan } \\
\text { - Risk monitoring and control } \\
\text { - Project risk planning after approval and } \\
\text { notification of the project to the project } \\
\text { manager } \\
\text { - Update information related to risks and } \\
\text { during the project and in control processes } \\
\text { - Training project managers to get } \\
\text { acquainted with project management } \\
\text { knowledge and the importance of paying } \\
\text { attention to the field of risk management } \\
\text { - Preparing and compiling local models } \\
\text { required for project risk management and } \\
\text { requiring project managers to implement } \\
\text { processes based on codified models } \\
\text { - special attention to knowledge management } \\
\text { and make it possible to use the experiences of } \\
\text { previous projects }\end{array}$ \\
\hline
\end{tabular}

